\title{
Types of Recasts (Full and Partial) and Grammatical Structures by Basic Level EFL Iranian Learners
}

\author{
Ali Elhami ${ }^{1} \&$ Anita Roshan ${ }^{1}$ \\ ${ }^{1}$ MA in Applied Linguistics, English Language Teacher, Tehran, Iran \\ Correspondence: Ali Elhami, MA in Applied Linguistics, Tehran, Iran. E-mail: a.elhami.ali@gmail.com
}

Received: February 28, 2016 Accepted: April 11, 2016 Online Published: May 25, 2016

doi:10.5539/ijel.v6n3p176 URL: http://dx.doi.org/10.5539/ijel.v6n3p176

\begin{abstract}
The study was designed to show if the full and partial recast given to third person "s" or simple past "ed" caused learners to generate various kinds of output. 32 EFL learners at the elementary level participated in the current research. They were divided in two different groups, one included 18 and the other 14 learners. After recording their voice while giving them full and partial recast, regarding data analysis, chi Square and Paired-Samples t-test were run to analyze the data. The hypothesis was retained, leading us to conclude that full and partial recast did not function differently in simple past "ed" and the third person "s". In doing so, it aims to help teachers to better understand the effectiveness of full recast and partial recast in different grammatical structures.
\end{abstract}

Keywords: implicit and explicit knowledge, implicit and explicit feedback, corrective feedback, types of recasts (full and partial), grammatical structures

\section{Introduction}

Making errors while interacting with others emanates from lack of competence. While interaction is going on, a learner may have difficulty generating the correct forms. Here, the teacher or peers may give him/her feedback on the erroneous structures.

All types of corrective feedback have positive effect on second language learning. However, among all types, recast has proved more outstanding. Trofimovich, Ammar, \& Gatbonton (2011) assert that recasts are important, and they improve L2 development in the context of meaningful interaction.

Recast can be one of the best forms of feedback. Gass \& Selinker (2008) assert that "recasts are another form of feedback; though they are less direct and more subtle than other forms of feedback. A recast is a reformulation of an incorrect utterance that maintains the original meaning of the utterance" (p. 334).

Guided by the above considerations, recast has been regarded as one of the most effective feedbacks over the recent decade. Researchers and scholars have studied various kinds of recasts, especially full and partial recast, and their effects on second language learning development.

Recast can be classified into different types. As Gass \& Selinker (2008) point out, recasts are complex, because of different types. The teacher may respond to an error by using one type or more.

Another factor to be taken into consideration is the output. Whether a learner modifies his or her output followed by a recast type is an important issue. The output may be unmodified, less modified, and modified.

This output is believed to play an important role in language learning. Swain (2005, as cited in Brown, 2007) has suggested three major functions of output in SLA. The first is the claim that while attempting to produce the target language, learners may notice their erroneous attempts to convey meaning. Also, he further believes that the act of producing language itself can prompt learners to identify their language deficiencies. Here, leaners become self-informed through their own output. The second function of output, according to Swain, is that it serves as a means to try out one's language, to test various hypotheses that are forming. He maintains that the third function fits appropriately in a social constructivist view of SLA: speech and writing can offer a means for the learners to reflect productively on language itself in interaction with peers.

When learners receive corrective feedback they try to modify their output, so corrective feedbacks help learners to modify their output. Alison Mackey (2012) points out that "learners are pushed to reformulate their initial utterance in other to facilitate native speakers' understanding by modifying their linguistic output in a more 
target like way" (p. 17).

\subsection{Research Question}

Q. Do full recast and partial recast make a statistically significant difference in different grammatical structures, that is third person "s" and simple past "ed", by basic level EFL Iranian learners?

\subsection{Research Hypothesis}

Ho: Full recast and partial recast do not make a statistically significant difference in different grammatical structures, that is third person "s" and simple past "ed", by basic level EFL Iranian learners.

\subsection{Literature Review}

\subsubsection{Implicit vs. Explicit L2 Knowledge}

Implicit and explicit knowledge are two different types of knowledge by which people can learn new things in different ways. Catherin Van Beuningen (2010) has claimed that:

An often referred issue in the field of instructed SLA is the role of conscious grammar knowledge in becoming a proficient user of the L2. Conscious knowledge about the L2 grammatical system has been widely referred to as explicit or declarative knowledge, and opposed to implicit or procedural knowledge (Bialystok, 1994; DeKeyser, 1998; Krashen, 1981; DeKeyser, 2003). Explicit knowledge is a conscious awareness of grammatical rules and the appropriate meta-language for verbalizing this knowledge (Ellis, 2004). On the other hand, implicit knowledge is unconscious, non-verbalizable, and easily accessible during online language use (Beuningen, 2010). (p. 7).

The current assumption is that it is learners' implicit L2 knowledge that enables them to communicate fluently and spontaneously. However, "how the type of explicit knowledge resulting from grammar instruction contributes to the SLA process has been and remains today one of the most controversial issues in language pedagogy" (Ellis, 2005, p. 214).

Disagreements deal with both the value of explicit knowledge and the connection between implicit and explicit knowledge. This debate is critical when exploring the effectiveness of error correction, since CF contestants (e.g., Krashen, 1982; Truscott, 1996) have asserted that, if CF yields any L2 knowledge at all, this emerging knowledge could only be explicit in nature (Beuningen, 2010).

Opponents to the use of CF in L2 classrooms, such as Krashen (1982), argue that the benefits of explicit knowledge are rather limited. In Krashen's view, learners can only use their explicit L2 knowledge during monitoring (i.e., editing of output after it has been initiated by the acquired system), and not in online language use. In exploring the effect of online planning time on learners' oral language performance, Yuan \& Ellis (2003) identified that the available planning time developed the accuracy of learners' online production. This finding offers that learners are able to access their explicit knowledge online, and therefore the value of conscious L2 knowledge is not restricted to monitor the use (Ellis, 2005).

Irrespective of the value of explicit knowledge, it might be the case that explicit knowledge helps the improvement of implicit knowledge. However, those opposing the effectiveness of CF adhere to the position that implicit and explicit knowledge systems are entirely distinct, without an interface connecting them. This view is strongly related to Krashen's $(1981,1982,1985)$ proposed distinction between learning and acquisition.

\subsubsection{Types of Corrective Feedback}

Despite research studies which have been conducted on error correction and feedback for L2 learners, still some controversies have remained and there is no clear cut answer to this question that which type of feedback may suit learners the best. There are some research studies which have taken the influence of error feedback into consideration; however, the findings are conflicting. Some examples of these studies and interpretation of the results will be provided in the final parts of this chapter.

Corrective feedback falls into the two categories, namely implicit and explicit feedback which will be discussed as follows.

\subsubsection{Explicit Feedback}

Explicit feedback refers to "the types that include stress or emphasis on the feature being corrected. In such a case feedback is delivered through explicit rule statements, in oral, manual, or written mode; via some form of overt error correction" (Nassaji, 2009, p. 412).

Ferris \& Roberts (2001) studied on an extent in which error feedback needs to be explicit so in this case learners 
get to self-edit their texts. They believe that their results are in light of Krashen's (1982) Monitor Hypothesis, which states that and explicit knowledge and formal learning are acting as an editor which operates when students are focused on form intentionally, when students know the involved rule, and have sufficient time to think on it and apply their knowledge. In their research study, the group receiving feedback outperformed the group receiving no feedback in editing their outcomes; nevertheless, coded feedback had no significant and noticeable effect. They were not the only researchers see themselves ending up with this issue, in second language learning, the main body of research has been immensely in line with Krashen's claim that learners only learn through unconscious acquisition. He believes, when learning is consciously done, it does not lead to acquisition, which is supposed to be unconscious, and acts only as a monitor. On the other hand, some other researchers (Ellis, 1991; Schmidt, 2001) believe that learners' attention to forms is required for learners.

There are also some other studies which show the benefit of using explicit feedback. In Carroll \& Swain (1993) and Carroll (2001), it is proven that direct metalinguistic feedback could outperform all other types of correction. In Muranoi (2000) study, formal grammatical explanation was more beneficial than meaning-focused debriefing. Some classroom studies, which are done by Leow $(1998)$, and Scott $(1989,1990)$ have also indicated that explicit correction can be more helpful than implicit correction.

\subsubsection{Implicit Feedback}

"Implicit feedback has generally been regarded as a form of corrective feedback" (Sheen, 2008, p. 836) in which the corrections are done indirectly via teacher's reformulation of all or part of a student's utterance minus the error.

Implicit feedback, on the other hand, refers to the response of the teacher or some time the peers to a student's errors without directly mentioning that an error has been made (Ellis, Basturkmen, \& Loewen, 2001). Both explicit and implicit feedbacks are mainly used by teachers in classes. Nevertheless, corrective feedback and its different types are still being discussed by researchers in terms of their effectiveness.

The significance of this study can be investigated from two main perspectives: theoretically and practically. Theoretically, the researchers would benefit from this study in a sense that they would come up with a better distinction between full recast and partial recast. Previously, recast used to be of one single type, but it is going to be of different types. If they generate different kinds of output, a clear distinction line can be drawn between full and partial recast.

Practically, this study would be helpful to teachers in a way that they would gain a better understanding of the effectiveness of full and partial recast, although there is consensus among researchers that recast cannot necessarily lead to learning. If either of them leads to better learning and noticing, the teachers can use it to improve their students' learning.

\section{Method}

Recast is one of the most important corrective strategies which is highly recommended by researchers. However, that it is very effective in all circumstances is not very clear. It has got a variety of different forms, two of which are full and recast. The present study aims to see whether partial and full recast acted differently with regard to different grammatical structures

\subsection{Participants}

The researcher administered an Oxford Placement Test in order to choose only elementary learners in one of the language schools in Tehran, Iran. Those whose scores fall between 0 to 14 are considered elementary learners. One group included 14 and the other 18 learners. The above learners are considered one group, but they were divided into two groups, because the researcher did not want to have the effect of priority of full or partial recast, and he used at first full recast then partial recast in one group and for another group he used partial recast then full recast.

\subsection{Instruments and Materials}

There are two parts in this test: the first part (question 1 to 40 ) includes 40 items, all the students in the two groups were asked to answer the questions. There is a time limitation of 30 minutes to answer the items on the answer sheet.

\subsection{Short Story}

A short story based on the grammatical rule by which full and partial recasts are comparing, was given to the learners in which the grammatical rule in the story was bolded. 


\subsection{Picture Description}

The learners in all groups were given a picture to describe it. The learners were given partial and full recast throughout their descriptions and their voices were recorded. The researcher asked all the individual learners to describe the pictures. The purpose of this task was to elicit output from the learners and to give full and partial recast if an utterance was wrong.

\subsection{Audio Recording}

The learners' output following the full recast and partial recast was recorded. The researcher recorded their voices using a high tech recorder.

\subsection{Procedures}

At first, the researcher used Oxford Placement Test to select learners in elementary level. Then a short story was given to the students. In this short story the grammatical points (the third person "s") were bolded and learners read this short story for two minutes. The full and partial recast in the present study were applied to this grammar point: the third person "s". The two groups were given a picture description task. And the teacher asked then about the pictures, for example he showed picture of a woman who was getting up at 6am and asked the learner, what does she do at 6am? Each learner was required to describe it and use the third person "s" if they made error, the researcher gave the full recast and the next time partial recast in one group and for another group everything is the same but just the teacher gave them at first partial recast then full recast. The learners in two groups were given a noticing task, which was a short story with ten wrong uses of the third person "s" to be identified and corrected. Then the same story happened for the other grammatical structure which was the regular past tense.

\section{Results}

The research question of the present study asked whether full and partial recasts do not make a statistically significant difference in different grammatical structures. In order to answer this question, the analysis of crosstabs (two-way Chi-square) was performed for both third person and simple past grammatical structures on modified output, and Paired Samples Test was conducted to both third person and simple past grammatical structures on noticing.

\subsection{Modified Output}

Table 1 shows the frequencies, percentages and standardized residuals (Std. Residual) for the false and true modified output answers of the students in the partial and full recast conditions for third person.

Table 1 depicts that $0.0 \%(0 / 16)$ of the answers was "False" in full recast, but $31.3 \%(5 / 16)$ of the answers were "False" in partial recast for third person. Besides, Table 4.8 shows that $100.0 \%(16 / 16)$ of the answers were "True" in full recast; nonetheless $68.8 \%(11 / 16)$ of the answers were "True" in partial recast for third person.

Table 1. Frequencies, percentages and Std. residuals for the false and true modified outputs in the partial and full fecasts (third person)

\begin{tabular}{|c|c|c|c|c|c|}
\hline & & & \multicolumn{2}{|l|}{ Answer } & \multirow{2}{*}{ Total } \\
\hline & & & False & True & \\
\hline \multirow{6}{*}{ Recast type } & & Count & 0 & 16 & 16 \\
\hline & Full & \% within Recast type & $.0 \%$ & $100.0 \%$ & $100.0 \%$ \\
\hline & & Std. Residual & -1.6 & .7 & \\
\hline & & Count & 5 & 11 & 16 \\
\hline & Partial & \% within Recast type & $31.3 \%$ & $68.8 \%$ & $100.0 \%$ \\
\hline & & Std. Residual & 1.6 & -.7 & \\
\hline \multirow{2}{*}{ Total } & & Count & 5 & 27 & 32 \\
\hline & & $\%$ within Recast type & $15.6 \%$ & $84.4 \%$ & $100.0 \%$ \\
\hline
\end{tabular}

Table 2 presents the results of chi-square that was used to find any significant difference in noticing in the partial and full recasts (third person). 
Table 2. Chi-square test for comparing the false and true modified outputs in the partial and full recasts (third person)

\begin{tabular}{|c|c|c|c|c|c|}
\hline & Value & df & Asymp. Sig. (2-sided) & Exact Sig. (2-sided) & Exact Sig. (1-sided) \\
\hline Pearson Chi-Square & $5.926^{\mathrm{a}}$ & 1 & .015 & & \\
\hline Continuity Correction ${ }^{\mathrm{b}}$ & 3.793 & 1 & .051 & & \\
\hline Likelihood Ratio & 7.863 & 1 & .005 & & \\
\hline Fisher's Exact Test & & & & .033 & .022 \\
\hline Linear-by-Linear Association & 5.741 & 1 & .017 & & \\
\hline $\mathrm{N}$ of Valid Cases & 32 & & & & \\
\hline
\end{tabular}

The assumption of performing Chi square is that the lowest expected frequency in any cell should be 5 or more (at least 80 percent of cells should have expected frequencies of 5 or more). We have violated this assumption and therefore we should consider using Fisher's Exact Probability test instead because 50.0\% have expected frequency less than 5 in our data.

The results of chi-square in Table 2 revealed that the differences watched in Table 1 are statistically significant $\left(x^{2}(1)=3.79, n=32, p=.03, p<.05\right)$ in which the value of Yates' Correction for Continuity was 3.79, and the $p$ value, .03 was below than the selected significant level for this study, .05. In other words, it was found that full and partial recasts did not influence learning the third person in noticing sensed by the learners differently.

Table 3 displays the frequencies, percentages and standardized residuals (Std. Residual) for the false and true modified output answers of the students in the partial and full recast conditions for simple past. Table 3 depicts that $100.0 \%(13 / 13)$ of the answers were "True" in full recast, and $100.0 \%(9 / 9)$ of the answers were "True" in partial recast for simple past.

Table 3. Frequencies, percentages and std. residuals for the false and true modified outputs in the partial and full recasts (simple past)

\begin{tabular}{|c|c|c|c|c|}
\hline & & & $\begin{array}{l}\text { Answer } \\
\text { True }\end{array}$ & Total \\
\hline \multirow{6}{*}{ Recast type } & \multirow{3}{*}{ Full } & Count & 13 & 13 \\
\hline & & $\%$ within Recast type & $100.0 \%$ & $100.0 \%$ \\
\hline & & Std. Residual & .0 & \\
\hline & \multirow{3}{*}{ Partial } & Count & 9 & 9 \\
\hline & & $\%$ within Recast type & $100.0 \%$ & $100.0 \%$ \\
\hline & & Std. Residual & .0 & \\
\hline Total & & Count & 22 & 22 \\
\hline
\end{tabular}

Crosstab Chi square could not be performed since none of the answers were false (all the answers were true). Therefore we could conclude that the effectiveness of full and partial recast on teaching the third person in noticing sensed by the learners was not dramatically different.

\subsection{Noticing}

In order to see whether full and partial recasts make a statistically significant difference in third person on noticing, parametric Paired Sample Test rather than nonparametric Wilcoxon Signed Rank Test was used because the three assumptions of interval data, independence of subjects and normality were met.

One-Sample Kolmogorov-Smirnov Test of normality (Table 4) showed that the two sets of scores had normal distribution because the Sig. was .30 and .24 for the two sets of scores respectively which are both above. 05 .

Table 4. One-sample kolmogorov-smirnov test of normality for noticing scores on full and partial recasts (third person)

\begin{tabular}{lllll}
\hline Group & $\mathrm{N}$ & Mean & Kolmogorov-Smirnov Z \\
\hline Full & 32 & 6.34 & .969 & Sig. \\
Partial & 32 & 6.16 & 1.028 & .304 \\
\hline
\end{tabular}


The descriptive statistics for noticing scores on full and partial recasts were calculated and are provided in Table 5 below before discussing the results of Paired Sample Test. Table 5 reflects that the third person mean obtained on full recast in noticing $(M=6.34, S D=2.98)$ was not noticeably different from the noticing mean acquired on partial recast $(M=6.16, S D=3.28)$.

Table 5. Descriptive statistics for noticing scores on full and partial recasts (third person)

\begin{tabular}{lllll}
\hline Recast type & Mean & $\mathrm{N}$ & Std. Deviation & Std. Error Mean \\
\hline Full & 6.34 & 32 & 2.98 & .527 \\
Partial & 6.16 & 32 & 3.28 & .580 \\
\hline
\end{tabular}

The results of paired samples test that was performed to compare third person means on full and partial recasts are laid out in Table 6.

Table 6. Paired samples test to compare noticing means on full and partial recasts (third person)

\begin{tabular}{lllllll}
\hline \multirow{2}{*}{ Mean } & \multirow{2}{*}{$\mathrm{SD}$} & $\mathrm{t}$ & \multirow{2}{*}{ df } & Sig. (2-tailed) & \multicolumn{2}{c}{ 95\% Confidence Interval of the Difference } \\
& & & & Lower & Upper \\
\hline .188 & 1.891 & .561 & 31 & .579 & -.494 & .869 \\
\hline
\end{tabular}

Paired-Samples t-test results (Table 6) revealed a statistically significant difference in noticing scoreson third person from partial recast $(M=6.34, S D=2.98)$ to full recast $(M=15.13, S D=4.70)$, with $\left(t_{(31)}=.56, p=.57\right.$, $p>.05$ (two-tailed)), in which the $t$-observed, .56, was lower than the $t$-critical, 2.04 , and also the $p$ value, .57 exceeded .05 . The mean increase in noticing scores was .18, which is very small, with a $.95 \%$ confidence interval ranging from -.494 to .869 . In fact full and partial recast did not influence learning the third person in noticing sensed by the learners differently.

In order to find out whether full and partial recasts make a statistically significant difference in simple past in noticing, nonparametric Wilcoxon Signed Rank rather than parametric Paired Sample Test was employed since the normality assumption was violated. The results of One-Sample Kolmogorov-Smirnov Test, as presented in Table 7 indicated that the two sets of scores were not normally distributed since the Sig. was .002 and .007 for the two sets of scores respectively which are both less than .05 .

Table 7. One-sample kolmogorov-smirnov test of normality for noticing scores on full and partial recasts (simple past)

\begin{tabular}{lllll}
\hline Group & $\mathrm{N}$ & Mean & Kolmogorov-Smirnov Z & Sig. \\
\hline Full & 32 & 8.78 & 1.838 & .002 \\
Partial & 32 & 8.44 & 1.689 & .007 \\
\hline
\end{tabular}

Table 8 depicts the descriptive statistics for noticing (simple past) scores on full and partial recasts. According to Table 8 , the simple past mean acquired on full recast in noticing $(M=8.78, S D=2.32)$ was not markedly different from the noticing mean acquired on partial recast $(M=8.44, S D=2.47)$. Besides, the median score on the full recast $(M d=10)$ was exactly the same as the median score $(M d=10)$ on the partial recast.

Table 8. Descriptive Statistics for Noticing Scores on Full and Partial Recasts (Simple Past)

\begin{tabular}{|c|c|c|c|c|c|c|}
\hline \multirow[t]{2}{*}{ Recast type } & \multirow[t]{2}{*}{$\mathrm{N}$} & \multirow[t]{2}{*}{ Mean } & \multirow[t]{2}{*}{ SD } & \multicolumn{3}{|c|}{ Percentiles } \\
\hline & & & & $25^{\text {th }}$ & 50th (Median) & $75^{\text {th }}$ \\
\hline Full & 32 & 8.78 & 2.324 & 8.00 & 10.00 & 10.00 \\
\hline Partial & 32 & 8.44 & 2.475 & 8.00 & 10.00 & 10.00 \\
\hline
\end{tabular}

Table 9 represents the results of Wilcoxon Signed Rank Test that was used to compare simple past means on full and partial recasts. 
Table 9. Wilcoxon signed rank test to compare noticing means on full and partial recasts (simple past)

\begin{tabular}{ll}
\hline & Partial recast- Full recast \\
\hline$Z$ & $-1.298^{\mathrm{a}}$ \\
Asymp. Sig. (2-tailed) & .194 \\
\hline
\end{tabular}

A Wilcoxon Signed Rank Test (Table 9) revealed no statistically significant difference in simple past scores on the full and partial recasts in noticing task, $Z=-1.29, p=19, p<.0$, in which the $\mathrm{p}$ value (.19) was below 05 . That means full and partial recast did not affect learning the simple past in noticing sensed by the learners differently.

\section{Discussion}

The finding of the present research is not a little in agreement with the finding of the study done by Ellis, Loewen, \& Erlam (2006), who compared their learners' performance on tests of explicit and implicit knowledge of regular past tense in English. In the current research, the regular past tense was investigated. The results of the explicit knowledge test (a grammatical judgment task) indicated that the first group (metalinguistic) outperformed the no-feedback group and the recast group only on the delayed post-test. The researchers suggested that metalinguistic information might have been more effective since the learners might have perceived it as an overt correction method. In their study, thirty-four ESL learners in three classes performed two story-narration tasks and a number of tests over a three-week period. One class received metalinguistic information and the opportunity to respond, while the second class received recasts. The third class; however, received no interactional feedback. Although metalinguistic feedback was not investigated in the present research, it is regarded as more powerful than recast in the study done by Ellis, Loewen, \& Erlam (2006).

\section{Conclusion}

This hypothesis dealt with whether full and partial recast affected the regular past "ed" and the third "s" differently. Here, the main issue was the difference between two grammatical points. Mackey (2006) maintains that recast may function differently over different grammar structures. The results reflects that the third person mean obtained on full recast in noticing $(M=6.34, S D=2.98)$ was not noticeably different from the noticing mean acquired on partial recast $(M=6.16, S D=3.28)$.

Concerning the simple past, the descriptive statistics showed the simple past mean acquired on full recast in noticing $(M=8.78, S D=2.32)$ was not markedly different from the noticing mean acquired on partial recast ( $M$ $=8.44, S D=2.47)$. Besides, the median score on the full recast $(M d=10)$ was exactly the same as the median score $(M d=10)$ on the partial recast. Therefore, it can be concluded that full and partial recast did not function differently in the simple past "ed" and the third person "s".

\section{References}

Beuningen, C. (2010). Corrective feedback in L2 writing: Theoretical perspectives, empirical insights, and future directions. International Journal of English Studies, 10(2), 1-27.

Bialystok, E. (1994). Analysis and control in the development of second language proficiency. Studies in Second Language Acquisition, 16(2), 157-168. http://dx.doi.org/10.1017/S0272263100012857

Brown, H. D. (2007). Principles of language learning and teaching (5th ed.). White Plains, NY: Pearson Education Inc.

Carroll, S. (2001). Input and evidence: The raw material of second language Acquisition. Amsterdam: Benjamins. http://dx.doi.org/10.1075/lald.25

Carroll, S., \& Swain, M. (1993). Explicit and implicit negative feedback: An empirical study of the learning of linguistic generalizations. Studies in Second Language Acquisition, 15, 357-386. http://dx.doi.org/10.1017/S0272263100012158

DeKeyser, R. M. (1998). Beyond focus on form: Cognitive perspectives on learning and practicing second language grammar. In C. Doughty \& J. Williams (Eds.), Focus on form in classroom second language acquisition (pp. 42-63). Cambridge: Cambridge University Press.

DeKeyser, R. M. (2003). Implicit and explicit learning. In C. J. Doughty \& M. H. Long (Eds.), Handbook of second language acquisition (pp. 313-348). Oxford: Blackwell. http://dx.doi.org/10.1002/9780470756492.ch11

Ellis, R., Basturkmen, H., \& Loewen, S. (2001). Learner uptake in communicative ESL lessons. Language 
Learning, 51(2), 281-318. http://dx.doi.org/10.1111/1467-9922.00156

Ellis, R. (1991). Second language acquisition and language pedagogy. Clevedon: Multilingual Matters.

Ellis, R. (2004). Task-based language learning and teaching. Oxford: Oxford University press.

Ellis, R. (2005). Instructed second language acquisition: A literature review. Wellington: Ministry of Education, New Zealand. Retrieved from http://www.educationcounts.edcentre.govt.nz/publications/

Ellis, R., Loewen, S., \& Erlam, R. (2006). Implicit and Explicit Corrective Feedback and the Acquisition of L2 $\begin{array}{lllll}\text { Grammar. Studies in Second Language Acquisition, 28, 339-368. } & \text {. }\end{array}$ http://dx.doi.org/10.1017/s0272263106060141

Ferris, D., \& Roberts, B. (2001). Error feedback in L2 writing: How explicit does it need to be? Journal of Second Language Writing, 10(3), 161-184. http://dx.doi.org/10.1016/S1060-3743(01)00039-X

Gass, S. M., \& Selinker, L. (2008). Second language acquisition (3rd ed.). New York. NY: Routledge.

Krashen, S. (1981). Second language acquisition and second language learning. Oxford: Pergamon.

Krashen, S. (1985). The Input Hypothesis: Issues and implication. London and New York: Longman.

Krashen, S. D. (1982). Principles and practices in second language acquisition. Oxford: Pergamon Press.

Leow, R. P. (1998). Toward operationalizing the process of attention in SLA: evidence for Tomlin and Villa's fine grained analysis of attention (1994). Applied Psycholinguistics, 19, 133-159. http://dx.doi.org/10.1017/S0142716400010626

Mackey, A. (2006). Feedback, noticing and instructed second language learning. Applied Linguistics, 27(3), 405-430. http://dx.doi.org/10.1093/applin/ami051

Mackey, A. (2012). Input, Interaction, and Corrective feedback in L2 Learning (1st ed.). Oxford, United Kingdom.

Muranoi, H. (2000). Focus-on-form through interaction enhancement: Integrating formal instruction into a communicative task in EFL classrooms. Language Learning, 50, 617-673. http://dx.doi.org/10.1111/0023-8333.00142

Nassaji, H. (2009). Effects of recast and elicitations in syndic interaction and the role of feedback explicitness. Language learning, 59, 411-452. http://dx.doi.org/10.1111/j.1467-9922.2009.00511.x

Schmidt, R. (2001). Attention. In P. Robinson (Ed.), Cognition and second language instruction (pp. 3-32). Cambridge: Cambridge University Press. http://dx.doi.org/10.1017/CBO9781139524780.003

Scott, V. M. (1989). An empirical study of explicit and implicit grammar teaching strategies in French. Modern Language Journal, 73, 14-22. http://dx.doi.org/10.1111/j.1540-4781.1989.tb05303.x

Scott, V. M. (1990). Explicit and implicit grammar teaching strategies: new empirical data. French Review, 63, 779-789.

Sheen, Y. (2008). The effect of focused written corrective feedback and language aptitude on ESL learners' $\begin{array}{llll}\text { acquisition of } & \text { articles. }\end{array}$ http://dx.doi.org/10.1002/j.1545-7249.2007.tb00059.x

Swain, M. (2005). The output hypothesis: Theory and research. In E. Hinkel (Ed.), The handbook of research in second language teaching and learning (pp. 471-483). Mahwah, NJ: Lawrence Erlbaum.

Trofimovich, P., Ammar, A., \& Gatbonton, E. (2011). How effective are recasts? The role of attention, memory, and analytical ability. In A. Mackey (Ed.), Conversational Interaction in second language acquisition (pp. 172-195). Oxford: Oxford university press.

Truscott, J. (1996). The case against grammar correction in L2 writing classes. Language Learning, 13(4), 337-343. http://dx.doi.org/10.1111/j.1467-1770.1996.tb01238.x

Van Beuningen, C. (2010). Corrective Feedback in L2 Writing: Theoretical Perspectives, Empirical Insights, and Future Directions. IJES, 10(2).

Yuan, F., \& Ellis, R. (2003). The effects of pre-task planning and on-line planning on fluency, complexity and accuracy in L2 oral production. Applied Linguistics, 24. 1-27. http://dx.doi.org/10.1093/applin/24.1.1 


\section{Copyrights}

Copyright for this article is retained by the author(s), with first publication rights granted to the journal.

This is an open-access article distributed under the terms and conditions of the Creative Commons Attribution license (http://creativecommons.org/licenses/by/3.0/). 